\title{
Sprinkler and drip irrigation in the organic tomato for single crops and when intercropped with coriander ${ }^{1}$
}

\author{
Irrigação por aspersão e gotejamento em tomateiro orgânico em cultivo solteiro e \\ consorciado com coentro
}

\author{
Waldir Aparecido Marouelli*, Daniel Anacleto da Costa Lage ${ }^{3}$, Cristina Silveira Gravina ${ }^{4}$, Miguel Michereff \\ Filho $^{2}$ e Ronessa Bartolomeu de Souza ${ }^{2}$
}

\begin{abstract}
The objective of this study was to evaluate the influence of both sprinkler and drip irrigation systems on the organic production of the tomato, cultivar Duradouro, when cultivated both as a single crop and intercropped with coriander. The experiment was carried out in the Distrito Federal, Brazil, using a randomized block design with six replications and a $2 \times 2$ factorial arrangement for the treatments. There was no significant interaction between the factors of irrigation system and cropping system. The productivity and mass of the tomato fruits were not affected by the treatments, but for the coriander, productivity was higher under the sprinkler system. Drip irrigation hindered the development of late blight (Phytophthora infestans) and reduced the percentage of rotten fruit, whereas the incidence of powdery mildew (Leveillula taurica) and infestation by the tomato leafminer (Tuta absoluta) were higher under the sprinkler system. The volume of soil exploited by the roots of tomato plants was higher with the sprinkler system, while the water productivity index with the drip system was $47 \%$ higher than with the sprinkler system. Firmer fruits were produced under drip irrigation. The cultivation system had a significant effect on the occurrence of insect pests, with the tomato intercropped with coriander showing a lower percentage of damaged fruit due to the Tomato Leafminer and to Spodoptera eridania.
\end{abstract}

Key words: Solanum lycopersicum L. Coriandrum sativum L. Organic agriculture. Market tomato. Irrigation systems.

\begin{abstract}
RESUMO - Objetivou-se avaliar a influência da irrigação por aspersão e por gotejamento na produção orgânica de tomate de mesa, cultivar Duradouro, em cultivo solteiro e consorciado ao coentro. O experimento foi realizado no Distrito Federal, com delineamento em blocos ao acaso, seis repetições e tratamentos dispostos em arranjo fatorial 2 x 2 . Não houve interação significativa entre os fatores sistema de irrigação e sistema de cultivo. A produtividade e a massa de frutos de tomate não foram afetadas pelos tratamentos, mas a produtividade de coentro foi maior na aspersão. A irrigação por gotejamento desfavoreceu o desenvolvimento da requeima (Phytophthora infestans) e reduziu o percentual de frutos podres, enquanto que o controle da incidência do oídio (Leveillula taurica) e a da infestação da traça-do-tomateiro (Tuta absoluta) foram maiores no sistema de aspersão. O volume de solo explorado pelas raízes do tomateiro foi maior na aspersão, enquanto o índice de produtividade da água no gotejamento foi $47 \%$ maior que na aspersão. Frutos mais firmes foram produzidos com irrigação por gotejamento. $\mathrm{O}$ sistema de cultivo teve efeito significativo sobre a ocorrência de insetos-praga, sendo que tomateiro consorciado com coentro apresentou menor percentual de frutos com danos por traça-do-tomateiro e por broca-grande (Spodoptera eridania).
\end{abstract}

Palavras-chave: Solanum lycopersicum L. Coriandrum sativum L. Agricultura orgânica. Tomate de mesa. Sistemas de irrigação.

\footnotetext{
*Autor para correspondência

${ }^{1}$ Recebido para publicação em 08/10/2012; aprovado em 25/06/2013

Pesquisa realizada com apoio financeiro parcial do CNPq e CDTOrg-DF

²Embrapa Hortaliças, Brasília-DF, Brasil, waldir.marouelli@embrapa.br, miguel.michereff@embrapa.br, ronessa.souza@embrapa.br

${ }_{3}^{3}$ Departamento de Fitopatologia, Universidade de Brasília, Brasília-DF, Brasil, danielcostalage@gmail.com

${ }^{4}$ Programa de Pós-Graduação em Agronomia, Universidade Federal de Goiás, Goiânia-GO, Brasil, crisgravina@gmail.com
} 


\section{INTRODUCTION}

The search for healthy foods which are free from contamination by pesticides has been increasing, with the rate of growth of the organic sector in Brazil reaching 30\% per year (BRANCO et al., 2010). Among the vegetables produced under organic systems, the tomato (Solanum lycopersicum L.) is one of the most sought after by Brazilian consumers, as its production under conventional systems demands the intensive use of pesticides. However, there are great difficulties in cultivating the tomato under organic systems due to phytosanitary problems that this crop presents, this being one of the main factors that makes the cost of the organic tomato far superior to those produced under a conventional system (MAROUELLI et al., 2011a; SCHALLENBERGER et al., 2008).

The efficient use of natural resources in organic systems of production is critical to the sustainability of the system. Among these resources, water, which is usually applied through irrigation, is probably the most vital for the production of the tomato. Besides supplying hydric needs, water is responsible for the solubilisation and availability of soil nutrients to the plants.

There is a close relationship between the incidence of some diseases and insect pests and the way water is supplied to the tomato plants. The conditions that favour the majority of diseases are the existence of free water on the leaves, and high water content in the soil. Thus, irrigation by overhead sprinkler may aid dispersion and provide a microenvironment which is favourable to infection by various pathogens that attack the shoots. On the other hand, sprinkler irrigation discourages the progress of powdery mildew, since the impact of the water droplets acts by mechanically reducing the number of spores on the leaf surface (LOPES, MAROUELLI; CAFÉ FILHO, 2006).

Drip or furrow irrigation systems, unlike sprinklers, minimize the incidence of disease in the tomato shoots by not wetting the plants, but favour those diseases caused by pathogens in the soil, especially under conditions of poor drainage (MAROUELLI; LOPES; SILVA, 2005).

Unlike most conventional producers of fresh tomatoes, who basically use furrow and drip irrigation systems, sprinklers have been used by organic farmers (TOGNI et al., 2009), especially as a way to control powdery mildew and some insect pests (LOPES; MAROUELLI; CAFÉ FILHO, 2006; MEDEIROS; SUJII; MORAIS, 2011).

In organic production systems, environmental diversification is critical to achieving balance in the system. Recent work (MAROUELLI et al., 2011a; MEDEIROS;
SUJII; MORAIS, 2009) has shown that the cultivation of coriander (Coriandrum sativum L.) intercropped with the tomato may reduce the population densities of tomato leafminer (Tuta absoluta (Meyr.) and whitefly (Bemisia tabaci Genn., biotype B). According to Togni et al. (2010), volatiles exhaled by the coriander have a repellent effect on some insect pests, and their flowers are frequently visited by many natural enemies, especially flies of the Syrphidae family and parasitic Hymenoptera.

The aim of this study was to evaluate the effect of sprinkler and drip irrigation on the organic production of the fresh tomato when cultivated is a single plant and when intercropped with coriander, in the Cerrado region of central Brazil.

\section{MATERIAL AND METHODS}

The experiment was carried out at the Research and Organic Production Area of Embrapa Vegetables, in the District Federal of Brazil, from May to October, 2009. The soil of the area is classified as a typical Red Latosol in the cerrado stage, having a clay-like texture (60\% clay, $34 \%$ silt and $6 \%$ sand) and a water retention capacity of $1.2 \mathrm{~mm} \mathrm{~cm}^{-1}$.

The average air temperature and relative humidity during the development cycle of the tomato plants were $20.3{ }^{\circ} \mathrm{C}$ and $72 \%$ respectively, with minimum averages of $14.0{ }^{\circ} \mathrm{C}$ and $43 \%$ and maximum averages of $29.6{ }^{\circ} \mathrm{C}$ and $90 \%$ (Figure 1). The data were collected by means of digital thermo-hygrometers installed among the tomato plants in four climatological shelters $(0.32 \mathrm{~m} \mathrm{x}$ $0.30 \mathrm{~m} \times 0.35 \mathrm{~m}), 0.20 \mathrm{~m}$ from the soil surface.

The factors evaluated were the irrigation system (above-canopy sprinkler and drip) and the system of cultivation (tomato plants grown alone and intercropped with coriander), in a total of four treatments.

For the purposes of green fertilization, the experimental area had been previously planted with sunn hemp (Crotalaria juncea L.), which was incorporated into the ground about 30 days before sowing the coriander. Borders of forage sorghum (Sorghum bicolor (L.) Moench.) and sunn hemp were established around the experimental plots, both as windbreaks and to increase plant diversity in the production system. Also, contour lines lateral to the experimental area were retained with fixed barriers of Mexican sunflower (Tithonia diversifolia (Hemsl.) A. Gray) and elephant grass (Pennisettum purpureum Schum.). Chemical analysis of the soil before green fertilization showed: $\mathrm{pH}=6.1, \mathrm{P}=5.4 \mathrm{mg} \mathrm{dm}^{-3}, \mathrm{~K}$ $=285 \mathrm{mg} \mathrm{dm}^{-3}, \mathrm{Al}=0.00 \mathrm{cmol}_{\mathrm{c}} \mathrm{dm}^{-3}, \mathrm{Ca}=3,20 \mathrm{cmol}_{\mathrm{c}} \mathrm{dm}^{-3}$, $\mathrm{Mg}=2.330 \mathrm{cmol}_{\mathrm{c}} \mathrm{dm}^{-3}$ and organic matter $=46.6 \mathrm{~g} \mathrm{dm}^{-3}$. 
Figure 1 - Temperature, relative humidity (maximum, average and minimum) and rainfall values at the experimental area during the development cycle of the tomato plants. Federal District, Brazil, 2009

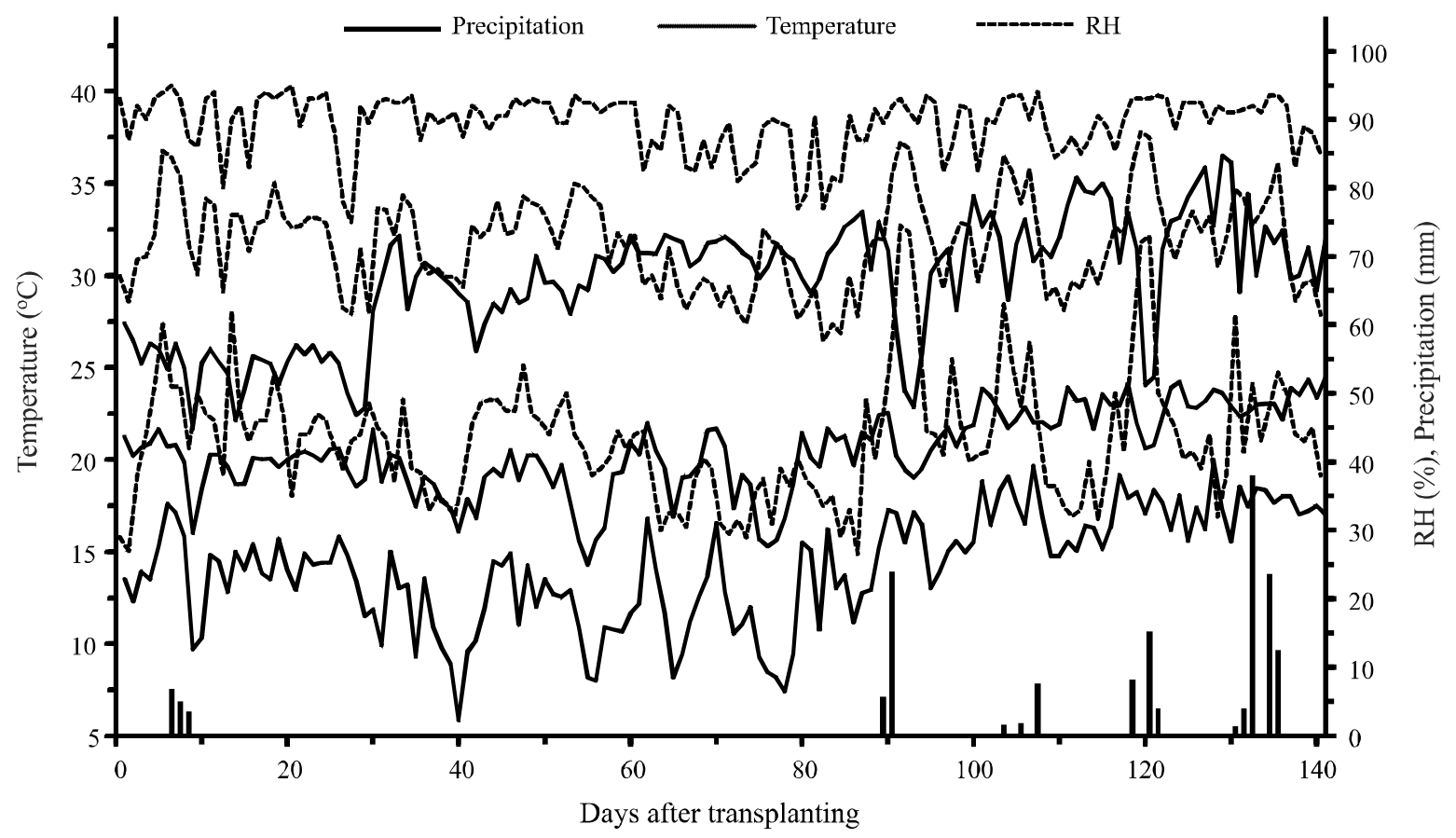

Thirty-day seedlings of the tomato, cultivar 'Duradouro', produced in trays of 128 cells with a commercial organic substrate, were transplanted on May 26th into a single row system, with a spacing of $1.00 \mathrm{~m} \times 0.50 \mathrm{~m}$. The experimental plots were composed of five $10.0 \mathrm{~m}$ rows of plants, giving a total area of $50.0 \mathrm{~m}^{2}$. Those tomato plants within $7.0 \mathrm{~m}$ of each of the three central rows were evaluated.

Pre-planting fertilization of the tomato was performed in all the experimental plots, five days before planting the coriander, using 2,500 $\mathrm{g}$ of organic compost $\left(1.5 \% \mathrm{~N}, 4.0 \% \mathrm{P}_{2} \mathrm{O}_{5}, 2.0 \% \mathrm{~K}_{2} \mathrm{O} ; 6.3 \% \mathrm{Ca}, 1.0 \% \mathrm{Mg}, 0.7 \%\right.$ $\mathrm{S}, 0.02 \% \mathrm{Zn}, 0.02 \% \mathrm{Cu}, 0.07 \% \mathrm{Mn}$ and $0.01 \% \mathrm{~B}$ ), and $250 \mathrm{~g}$ of magnesium thermophosphate $\left(17 \% \mathrm{P}_{2} \mathrm{O}_{5} ; 7 \% \mathrm{Mg}, 20 \%\right.$ $\mathrm{Ca})$ per linear metre of plant row, as adopted at Embrapa Vegetables for organic tomato production systems.

In those plots with intercropping, coriander, cultivar 'Verdão' was sown 10 days before the transplanting of the tomato plants, using $5 \mathrm{~g}$ of seeds per linear metre. Seeding took place where the organic compost and thermophosphate had been added and the tomato seedlings were then transplanted.

The tomato plants were trained vertically, with the use of trellis, on one branch and pruned to a height of $1.75 \mathrm{~m}$. Thinning was done weekly and weeding carried out every two weeks. At 45 and 95 days after the tomato seedlings were transplanted, $500 \mathrm{~g}$ of the same organic compost as that used before planting was applied per linear metre of plant row.

In all treatments, five sprayings were uniformly carried out, five of Bordeaux mixture, one of lime sulphur, two of emulsifiable neem oil, and three of biological insecticide with a base of Bacillus thuringiensis Berl. subsp. kurstaki. Any dead tomato plants or those with severe viral symptoms were removed.

The coriander was harvested at 50 days after sowing, leaving two plants to flower between every two tomato plants. The harvested coriander was then weighed with roots. The coriander was re-sown (3 g of seed per linear metre), and again harvested 50 days later, leaving another two plants to flower between every two tomato plants.

In those plots irrigated by overhead sprinkler, heads with a reach of $18 \mathrm{~m}$ and a flow rate of $4.58 \mathrm{~m}^{3} \mathrm{~h}^{-1}$ were used per sector, at an operating pressure of $200 \mathrm{kPa}$, and spaced $12 \mathrm{~m} \mathrm{x} 12 \mathrm{~m}$ apart. The sprinklers were first installed at a height of $0.5 \mathrm{~m}$ and then raised to $1.9 \mathrm{~m}$, always above the canopy of the tomato plants. To avoid wetting adjacent plots, the sprinklers were operated with a rotation of $90^{\circ}$. In the treatments using drip-irrigation, drip tubing was used with emitters spaced every $0.20 \mathrm{~m}$, with a flow rate of $1.4 \mathrm{~L} \mathrm{~h}^{-1}$. Two lateral lines of emitters were used per plant row, positioned $0.05 \mathrm{~m}$ from the side of each row until the start of flowering, and $0.15 \mathrm{~m}$ thereafter. 
Management of the irrigation water was carried out with the aid of tensiometers installed in all the experimental plots. The sensors were positioned in the centre of the plot between $0.10 \mathrm{~m}$ and $0.15 \mathrm{~m}$ from the plant and the dripper, and at $50 \%$ of the effective depth of the root system (MAROUELLI; SILVA, 2007), i.e. initially at a depth of $0.10 \mathrm{~m}$ and later $0.20 \mathrm{~m}$. Irrigation occurred whenever the average sensor readings reached between $25 \mathrm{kPa}$ and $40 \mathrm{kPa}$, with the lower limit being used during the fruiting stage which is more sensitive to water deficit (MAROUELLI; SILVA, 2007; MAROUELLI et al., 2011b).

In all treatments under the same irrigation system, both with single tomato plants and intercropped with coriander, water regimes were carried out simultaneously with the same amount of water. The amount of water applied was sufficient to return the soil to field capacity conditions at the soil layer equivalent to the effective root depth of the tomato plants, for those treatments with drip irrigation a ground-wetting factor of 0.65 was used, as determined in earlier field tests.

The fruit was harvested weekly at the mature green stage (FERREIRA; FREITAS; LAZZARI, 2004). The following variables of the tomato plants were evaluated: percentage reduction in stand; root concentration; total and marketable yield; percentage of waste fruit (by weight), total and marketable fruits per plant; weight of marketable fruit; percentage of rotten fruit, fruit damaged by the tomato leafminer and armyworm (Spodoptera eridania); severity of late blight caused by the oomycete Phytophthora infestans (Mont.) de Bary, and powdery mildew; water productivity index; macro and micronutrient content of the leaves; total soluble solids; total titratable acidity, firmness and fruit colour. The coriander was evaluated for productivity, expressed in $200 \mathrm{~g}$ bunches per hectare.

Included in the percentage reduction in stand, were dead plants and those eliminated due to severe viral symptoms. Fruit considered marketable were those with a diameter greater than $40 \mathrm{~mm}$ and no major defects (FERREIRA; FREITAS; LAZZARI, 2004). Fruits displaying rot, burn, physiological defects, and/or damage caused by mechanical means or by insect pests (> $1.5 \mathrm{~mm}$ ) were considered as being unmarketable. The water productivity index (WPi) was determined from the relation between the yield of marketable fruits and the total volume of water (effective rainfall and irrigation) delivered to the crop per unit area.

The concentration of tomato roots in the soil was determined by lattice profiling (MAROUELLI et al., 2011b). Evaluations were carried out after the last harvest, in three plants taken from one repetition of each treatment, by opening a trench $1.50 \mathrm{~m}$ deep, perpendicular to the rows of plants. Root concentration inside each mesh of $0.10 \mathrm{~m} \times 0.10 \mathrm{~m}$ was evaluated to a depth of $1.20 \mathrm{~m}$ using the following rating scale: 0 (no roots), 1 (very low concentration) 2 (low concentration), 3 (moderate concentration), 4 (high concentration) and 5 (very high concentration - $\max )$.

Quantification of disease was done a week before the last harvest. The severity of late blight was measured in 28 plants from each lot, using the James (1971) descriptive scale. To assess the severity of powdery mildew caused by Leveillula taurica (Lev.) Arnald (anamorph, Oidiopsis haplophylli Rulamort) in 14 plants from each lot, the diagrammatic scale of Boff, Zambolim and Vale (1991) was adapted.

The macro and micronutrient leaf content in the tomato was assessed at the time of anthesis of the third cluster. Leaves opposite that cluster, from 20 plants in each useful lot, were dried at $60{ }^{\circ} \mathrm{C}$ until reaching a constant weight, and ground in a Wiley knife mill. The material obtained was subjected to sulfuric acid digestion, to determine the nitrogen $(\mathrm{N})$, and perchloric acid and hydrogen peroxide digestion to test for other nutrients. The macro and micronutrient content was determined according to methods described by Nogueira and Souza (2005). With the exception of N, for which the distillation method (Kjeldahl) was used, all other nutrients were quantified by ICPE (plasma).

The total soluble solid content, titratable acidity, firmness and fruit colour were evaluated using protocols described by Moretti (2006). The physical and chemical analyses were carried out at the 2nd, 4th and 6th harvests on ten undamaged fruits selected from each plot, with a diameter of between $55-85 \mathrm{~mm}$ and in the red stage of maturation (FERREIRA; FREITAS; LAZZARI, 2004).

The amount of water applied via sprinkler irrigation was determined based on the average amounts from three collectors diagonally installed above the plants in four experimental plots. For drip irrigation, the amount was calculated by hydrometers installed at the entrance to the plots. Rainfall was measured with a Ville de Paris rain gauge, located $500 \mathrm{~m}$ from the experimental area, and the effective rainfall determined as per Marouelli et al. (2011b).

The experimental design was of randomized blocks, in a 2 x 2 factorial scheme, with six replications, totalling twenty-four plots. Data of amount of water applied, number of irrigations performed and root concentration of the tomato plants were evaluated in terms of the arithmetic mean, as they were quantified per treatment and not in all of the plots. The remaining data were subjected to variance analysis, taking $\mathrm{p}=0.05$ as the significance limit. 


\section{RESULTS AND DISCUSSION}

The development cycle of the tomato was 141 days in all treatments, with nine harvests being carried out, the first at 85 days after transplanting. The irrigation and cultivation systems therefore had no significant effect on the cycle of the tomato plant.

In those treatments irrigated by sprinkler, 28 irrigations were performed during the development cycle of the tomato plant, eight less than when irrigated by drip. As irrigation was carried out, taking into consideration the same limiting soil-water tension in all treatments, the higher number of irrigations by drip is mainly due to the lesser amount of water applied at each irrigation, being a result of the smaller volume of wet soil.

The total amount of water applied during irrigation of the tomato was $667 \mathrm{~mm}$ for sprinkler irrigation and $457 \mathrm{~mm}$ for drip irrigation. The saving of $31 \%$ of the water when using drip irrigation is primarily due to the fact that the system wets only a part of the soil surface, reducing water loss by evaporation, eliminates water loss by wind dispersion, and provides greater uniformity in the application of water than sprinkler systems under normal conditions of use (FERERES et al., 2003). Total rainfall during the development cycle of the tomato was $163 \mathrm{~mm}$ (Figure 1), the effective rainfall being estimated at $105 \mathrm{~mm}$ for sprinkler treatments and $72 \mathrm{~mm}$ for drip.

Root growth of the tomato plants was not influenced by the system of cultivation, but presented distinct behavior depending on the irrigation system used. Both lateral and vertical growths of the tomato roots were greater under sprinkler irrigation than when irrigated by drip (Figure 2). A low concentration of roots (level 2) was found to a depth of about $0.55 \mathrm{~m}$ in those plots irrigated by sprinkler, and $0.40 \mathrm{~m}$ in those irrigated by drip. As for lateral growth, in the soil profile down to a depth of $0.30 \mathrm{~m}$, the presence of roots at low concentration was seen up to $0.35 \mathrm{~m}$ on each side of the rows of those plants irrigated by drip, while for sprinkler, the roots took up the entire soil surface.

The lesser depth of the tomato roots under drip irrigation may occur according Phene, Hutmacker and Davis (1992) and Marouelli and Silva (2007), mainly because of irrigation being carried out more frequently than under the sprinkler system. Whereas the lesser lateral growth of the roots under drip irrigation was a result of the water being applied in a localized manner to only part of the soil profile. While the entire ground surface is irrigated using sprinklers, only a strip of wetness is formed along the plant rows when irrigating by drip.

There was no significant interaction between the irrigation system and cultivation system for any of the variables evaluated, showing similar responses for drip and sprinkler under both cultivation systems of the tomato. Marouelli et al. (2011a) also found similar responses of the tomato cultivar 'Pollyanna', irrigated under different systems, when grown alone and when intercropped with coriander.

Figure 2 - Root concentration (5 for maximum concentration; 0 for no roots) at the end of the development cycle of tomato plants irrigated by sprinkler (a) and by drip (b), assessed in the soil profile perpendicular to the row of plants. Federal District, Brazil, 2009
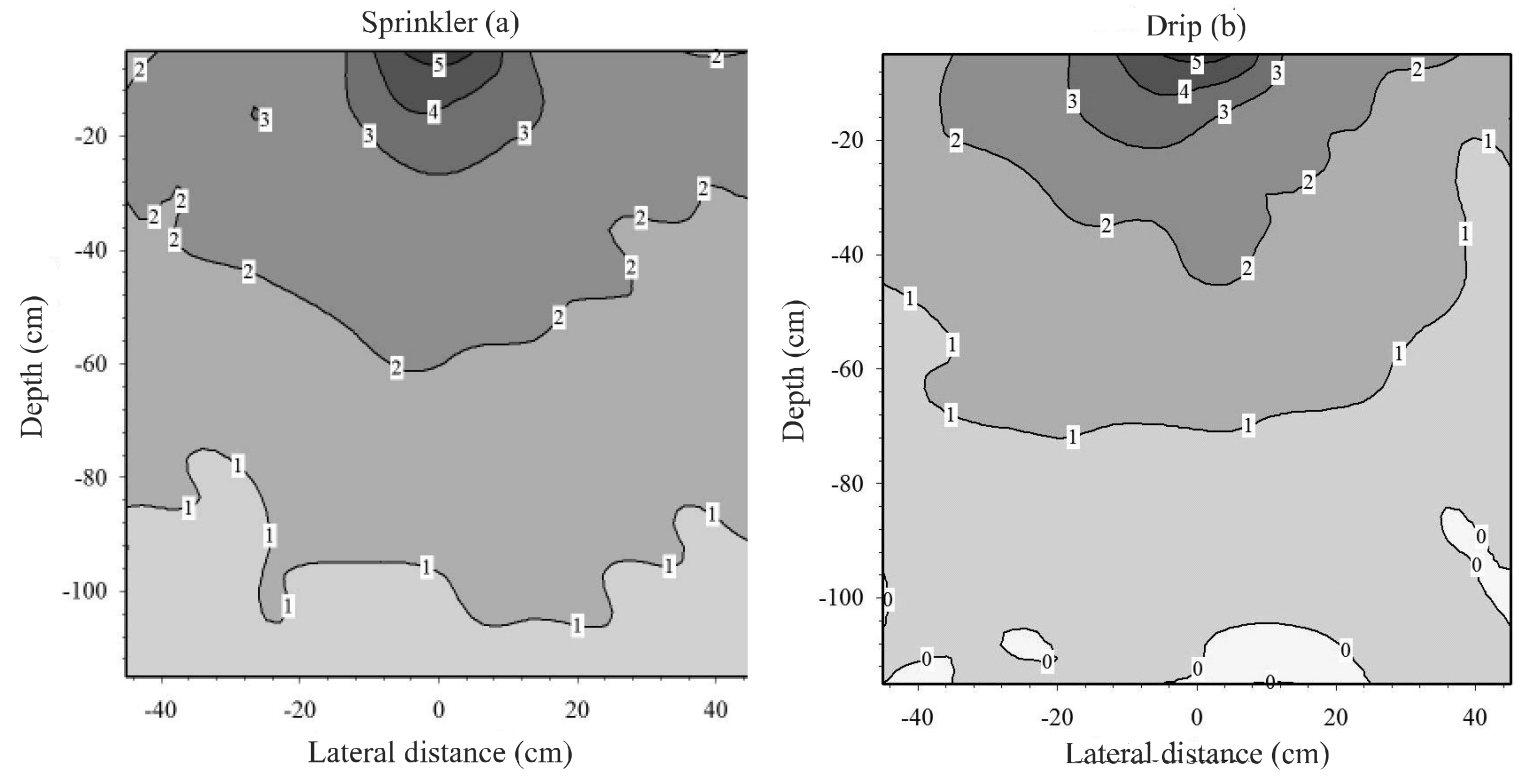
The final stand of the tomato plants, which was reduced by $18.2 \%$ on average, was not affected by the irrigation or cultivation methods (Table 1). This fact indicates that the treatments tested did not have different effects on the establishment of seedlings or the death of plants throughout the development cycle of the tomato.

Total fruit yield (average $82.2 \mathrm{Mg} \mathrm{ha}^{-1}$ ) and marketable yield (average $54.5 \mathrm{Mg} \mathrm{ha}{ }^{-1}$ ) were not significantly affected by the treatments (Table 1 ). These results are in agreement with Branco et al. (2010) and Marouelli et al. (2011a), who also found no variation in the productivity of the organic tomato whether irrigated by drip or sprinkler. This differs however from studies conducted in conventional production systems, where the yield of the tomato irrigated by drip is typically greater than when irrigated by sprinkler (HANSON, MAY, 2004; MAROUELLI et al., 2003). The reason for this difference may be exactly the fact that this study was carried out on an organic system. Four main factors may have limited the yield of the tomato under drip irrigation in the present work: the lower volume of soil used by the roots under drip treatments, limiting the absorption of nutrients; the non-application of soluble fertilizers through fertigation; the high severity of powdery mildew; and the greater loss of fruits to the tomato pinworm.

Although symptoms of nutritional deficiency in the tomato were not found, there was significant reduction in the absorption of nutrients by drip-irrigated plants (Table 2), possibly due to the smaller volume of soil used by the roots. According to Carvalho et al. (2005), the availability of nutrients from the soil in organic systems is slow and gradual because of the use of fertilizers of low solubility. For conventional production systems, Phene, Hutmacker and Davis (1992) reported that the use of drip irrigation in the tomato without the use of fertigation is inefficient, with a limited increase in yield due to the lower volume of soil used by the roots.
As for the system of cultivation, it was found that intercropping tomato with coriander did not significantly affect tomato yield, agreeing with Marouelli et al. (2011a) who used the cultivar 'Pollyanna'. Thus, coriander may be a good choice for diversifying the cultivation system of the tomato, since besides presenting a low level of competition, as also observed by Medeiros, Sujii and Morais (2009), it provides the producer with extra income.

Coriander yield however was significantly greater in the sprinkler-irrigated treatments $(48,800$ bunches $\left.\mathrm{ha}^{-1}\right)$ than the drip (41,300 bunches $\left.\mathrm{ha}^{-1}\right)$. The $15.4 \%$ reduction in productivity may have been due to the initial development of the coriander plants having been slower under drip irrigation. This result is supported by Smith et al. (2011), who recommend sprinkler irrigation during the initial phase of coriander production in order to improve germination and the establishing of the plants.

The percentage of waste fruit in the tomato under drip irrigation was significantly higher than when irrigated by sprinkler, which was due in part to the higher number of fruits damaged by borer insects, especially the tomato pinworm and armyworm. On the other hand, the total percentage of waste (average 33.4\%) was not affected by the system of cultivation (Table 1).

The evaluated treatments did not significantly affect the total number of fruits per plant (average 33.2) and the number of marketable fruits per plant (average 11.2). Similarly, marketable-fruit weight (average $150 \mathrm{~g}$ ) was not affected by the irrigation or cultivation systems (Table 1). Marouelli et al. (2003) and Marouelli et al. (2011a) also found no significant effect of the different irrigation systems on the weight of the tomato fruit.

Table 1 - Mean values for stand reduction, total and marketable yield, waste fruit, total and marketable fruit per plant, weight of marketable fruit, and water productivity index (WPi), according to the irrigation and cultivation system of the tomato (single and intercropped with coriander) and probability level of the F-test. Federal District, Brazil, 2009

\begin{tabular}{|c|c|c|c|c|c|c|c|c|}
\hline \multirow{2}{*}{ Irrigation system } & \multirow{2}{*}{ Stand reduction $(\%)$} & \multicolumn{2}{|c|}{ Yield $\left(\mathrm{Mg} \mathrm{ha}^{-1}\right)$} & \multirow{2}{*}{ Waste (\% weight) } & \multicolumn{2}{|c|}{ Number of fruits/plant } & \multirow{2}{*}{ Weight (g) } & \multirow{2}{*}{ WPi $\left(\mathrm{kg} \mathrm{m}^{-3}\right)$} \\
\hline & & Total & Market. & & Total & Market. & & \\
\hline Drip & 16.7 & 83.7 & 53.8 & 35.6 & 33.2 & 11.8 & 148 & 11.5 \\
\hline Sprinkler & 19.7 & 80.7 & 55.1 & 31.2 & 33.1 & 10.5 & 153 & 7.8 \\
\hline $\operatorname{Pr}>\mathrm{F}$ & 0.480 & 0.641 & 0.759 & 0.046 & 0.968 & 0.244 & 0.432 & 0.001 \\
\hline \multirow{2}{*}{ Cultivation system } & \multirow{2}{*}{ Stand reduction (\%) } & \multicolumn{2}{|c|}{ Yield $\left(\mathrm{Mg} \mathrm{ha}^{-1}\right)$} & \multirow{2}{*}{ Waste (\% weight) } & \multicolumn{2}{|c|}{ Number of fruits/plant } & \multirow{2}{*}{ Weight (g) } & \multirow{2}{*}{$\mathrm{WPi}\left(\mathrm{kg} \mathrm{m}^{-3}\right)$} \\
\hline & & Total & Market. & & Total & Market. & & \\
\hline Single & 15.3 & 87.5 & 57.0 & 34.8 & 33.8 & 11.8 & 151 & 10.0 \\
\hline Intercropped & 21.0 & 76.9 & 52.0 & 32.0 & 32.5 & 10.5 & 149 & 9.3 \\
\hline $\operatorname{Pr}>\mathrm{F}$ & 0.186 & 0.119 & 0.257 & 0.180 & 0.508 & 0.227 & 0.783 & 0.361 \\
\hline
\end{tabular}


The water productivity index under the system of drip irrigation was $47 \%$ higher than in when irrigated by sprinkling (Table 1). This increase is due to less water wastage with drip irrigation, as no significant change was observed in fruit yield between the two irrigation systems. A higher water productivity index in the tomato under drip irrigation is usually reported, both in conventional and organic production systems (MAROUELLI et al., 2011; PRIETO; LÓPES; BALLESTEROS, 1999). The system of cultivation did not affect the rate of water productivity of the tomato (average $9.6 \mathrm{~kg} \mathrm{~m}^{-3}$ ).

Based on the rating and classification of the fruits held every harvest, it was found that attack by armyworm was concentrated on the first two clusters of fruit on the plant, while the infestation of tomato pinworm came later and was found in bunches on the middle and upper third of the tomato plant. The percentage of fruits damaged by tomato pinworm was affected by both the systems of irrigation and cultivation (Table 3). The lowest levels of boring by the pinworm happened in those tomato plants which were intercropped with coriander and irrigated by sprinkler (4.2\% of damaged fruits). According to Lopes and Café Filho (2006) and Medeiros, Sujii and Morais (2011), a reduction in the infestation of tomato pinworm under sprinkler irrigation happens mainly due to the removal of eggs and small larvae by the impact of water droplets, especially on the upper third of staked tomato plants. Medeiros, Sujii and Morais (2009) and Togni et al. (2009) however, report that the coriander allows natural enemies of the tomato pinworm to become established.

The severity of armyworm attack on the tomato fruits (Table 3) was not affected by the irrigation system (average damage of $11.1 \%$ ). This was probably due to the armyworm preferring to infest the lower third of the plant. Deposits and defoliation by small caterpillars $(<5 \mathrm{~mm})$ were mainly observed in older leaves of the tomato plant. Therefore, the initial developmental stages of this pest seem to be better protected against the impact of water droplets by the architecture of the trained tomato plants themselves.

Attack by armyworm on the other hand, was influenced by the system of cultivation (Table 3). A lower percentage of fruit affected by armyworm was found in tomato intercropped with coriander than in single crops. In a similar way to that observed for tomato pinworm in the present study and for whitefly, by Togni et al. (2009), coriander also negatively affected armyworm infestation of the tomato plant.

The percentage of rotten fruits in those tomato plants irrigated by sprinkler was significantly higher than by drip, not having been affected by the system of cultivation (Table 3). The greater occurrence of rot in the fruits under the sprinkler system was possibly enhanced by injuries caused by borer insects and the damage to the fruits caused by $P$. infestans, which in the presence of moisture served as a 'gateway' for those microorganisms which cause rot (MAROUELLI et al., 2011a; REIS, 2010).

The severity of late blight was not influenced by the system of cultivation and was lower in those tomato plants irrigated by drip than by sprinkler (Table 3). As for powdery mildew, the intensity of the disease was greater when the plants were irrigated by drip, and low when irrigated by sprinkler. In a similar way to that observed for late blight, powdery mildew severity was not affected by the system of cultivation (Table 3 ).

While the experiment was being conducted there was dew formation for a few weeks in June and July. In those months, the relative humidity reached values equal to, or above $90 \%$ for $74 \%$ of nights, with minimum temperatures below $10{ }^{\circ} \mathrm{C}$ for $15 \%$ of the days, and average air temperatures between $14.3{ }^{\circ} \mathrm{C}$ and 21.7 ${ }^{\circ} \mathrm{C}$ (Figure 1). According to Lopes and Cafe Filho

Table 2 - Mean concentration values of macro and micronutrients in the tomato leaf, according to the irrigation and cultivation system of the tomato (single and intercropped with coriander) and probability level of the F-test. Federal District, Brazil, 2009

\begin{tabular}{|c|c|c|c|c|c|c|c|c|c|c|c|}
\hline \multirow{2}{*}{ Irrigation system } & \multicolumn{6}{|c|}{ 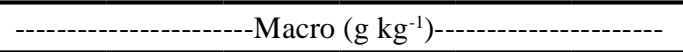 } & \multicolumn{5}{|c|}{----------Micro $\left(\mathrm{mg} \mathrm{kg}^{-1}\right)---{ }^{-}$} \\
\hline & $\mathrm{N}$ & $\mathrm{P}$ & $\mathrm{K}$ & $\mathrm{Ca}$ & $\mathrm{Mg}$ & $S$ & Bo & $\mathrm{Cu}$ & $\mathrm{Fe}$ & $\mathrm{Mn}$ & $\mathrm{Zn}$ \\
\hline Drip & 88.48 & 10.16 & 81.46 & 60.79 & 16.68 & 12.64 & 0.25 & 0.55 & 0.67 & 0.09 & 0.10 \\
\hline Sprinkler & 149.50 & 18.19 & 131.18 & 100.64 & 25.19 & 19.91 & 0.44 & 0.77 & 0.93 & 0.11 & 0.15 \\
\hline $\operatorname{Pr}>\mathrm{F}$ & 0.014 & 0.002 & 0.016 & 0.033 & 0.043 & 0.020 & 0.059 & 0.188 & 0.122 & 0.369 & 0.076 \\
\hline \multirow{2}{*}{ Cultivation system } & \multicolumn{6}{|c|}{$\operatorname{Macro}\left(\mathrm{g} \mathrm{kg}^{-1}\right)$} & \multicolumn{5}{|c|}{$\operatorname{Micro}\left(\mathrm{mg} \mathrm{kg}^{-1}\right)$} \\
\hline & $\mathrm{N}$ & $\mathrm{P}$ & $\mathrm{K}$ & $\mathrm{Ca}$ & $\mathrm{Mg}$ & $S$ & Bo & $\mathrm{Cu}$ & $\mathrm{Fe}$ & $\mathrm{Mn}$ & $\mathrm{Zn}$ \\
\hline Single & 118.06 & 15.09 & 104.45 & 75.65 & 19.52 & 16.88 & 0.32 & 0.67 & 0.67 & 0.09 & 0.12 \\
\hline Intercropped & 119.92 & 13.25 & 108.19 & 85.78 & 22.35 & 15.67 & 0.36 & 0.65 & 0.93 & 0.11 & 0.13 \\
\hline $\operatorname{Pr}>\mathrm{F}$ & 0.934 & 0.407 & 0.841 & 0.559 & 0.473 & 0.671 & 0.682 & 0.904 & 0.101 & 0.357 & 0.687 \\
\hline
\end{tabular}


Table 3 - Average values of fruit damaged by tomato pinworm, armyworm and rot, severity of late blight and powdery mildew, total soluble solids (TSS), firmness, total titratable acidity (TTA, in grams of citric acid/100g) and fruit colouration (factors L*, a*, b*), according to the systems of irrigation and cultivation of the tomato (single and intercropped with coriander) and probability level of the F-test. Federal District, Brazil, 2009

\begin{tabular}{|c|c|c|c|c|c|c|c|c|c|c|c|}
\hline \multirow{2}{*}{ Irrigation system } & \multicolumn{3}{|c|}{ Damaged fruits ( $\%$ number) } & \multicolumn{2}{|c|}{ Severity } & \multirow{2}{*}{ TSS ( ${ }^{\circ}$ brix) } & \multirow{2}{*}{$\begin{array}{l}\text { Firmness } \\
\left(\mathrm{N} \mathrm{cm}^{-2}\right)\end{array}$} & \multirow{2}{*}{ TTA } & \multicolumn{3}{|c|}{ Colour } \\
\hline & Pinworm & Armyworm & Rotten & Late blight & Powdery mildew & & & & $\mathrm{L}^{*}$ & $a^{*}$ & $b^{*}$ \\
\hline Drip & 10.0 & 11.4 & 3.7 & 1.5 & 45.4 & 3.35 & 11.5 & 1.52 & 44.9 & 16.1 & 26.3 \\
\hline Sprinkler & 4.8 & 10.7 & 5.9 & 11.4 & 2.6 & 3.54 & 7.6 & 1.46 & 45.9 & 15.6 & 27.7 \\
\hline $\operatorname{Pr}>\mathrm{F}$ & 0.001 & 0.683 & 0.004 & 0.016 & 0.001 & 0.100 & 0.002 & 0.077 & 0.086 & 0.198 & 0.370 \\
\hline \multirow{2}{*}{ Cultivation system } & \multicolumn{3}{|c|}{ Damaged fruits ( $\%$ number) } & \multicolumn{2}{|c|}{ Severity } & \multirow{2}{*}{ TSS ( ${ }^{\circ}$ brix) } & \multirow{2}{*}{$\begin{array}{l}\text { Firmness } \\
\left(\mathrm{N} \mathrm{cm}^{-2}\right)\end{array}$} & \multirow{2}{*}{ TTA } & \multicolumn{3}{|c|}{ Colour } \\
\hline & Pinworm & Armyworm & Rotten & Late blight & Powdery mildew & & & & $\mathrm{L}^{*}$ & $a^{*}$ & $b^{*}$ \\
\hline Single & 8.3 & 12.8 & 5.3 & 5.5 & 23.0 & 3.41 & 9.8 & 1.53 & 45.3 & 15.9 & 27.3 \\
\hline Intercropped & 6.4 & 9.0 & 4.4 & 7.4 & 25.1 & 3.47 & 9.4 & 1.53 & 45.4 & 15.9 & 27.0 \\
\hline $\operatorname{Pr}>\mathrm{F}$ & 0.025 & 0.049 & 0.152 & 0.625 & 0.078 & 0.592 & 0.716 & 0.892 & 0.538 & 0.907 & 0.312 \\
\hline
\end{tabular}

(2006), such climatic conditions favour the development of $P$. infestans, especially when using irrigation by sprinkler. Throughout the development cycle of the tomato plant, the average relative humidity of the air was $72 \%$, with humidity having been registered below $50 \%$ on $85 \%$ of the days (Figure 1). The low air humidity stimulated the development of Leveillula taurica mainly when irrigating by drip, which is due, according to Lopes and Café Filho (2006), to the absence of wetness on the leaf.

It was found that the joint occurrence of powdery mildew and pinworm at high severity levels in those plants under drip irrigation caused considerable damage to the foliage of the tomato from the second half of the crop cycle on. This fact probably affected, in a negative fashion, the rate of photosynthesis in the plants and may have contributed, along with less root development, to limit the yield of the tomato under drip irrigation.

The irrigation and cultivation systems did not affect the level of soluble solids, the titratable acidity or the colour parameters $\mathrm{L}^{*}, \mathrm{a}^{*}$ and $\mathrm{b}^{*}$ of the fruit (Table 3). Conversely, firmness of the fruits, which was not influenced by the cultivation system, was lower under the sprinkler system (Table 3 ).

The results for fruit quality were partly consistent with Prieto, Lopes and Ballesteros (1999), who also found no significant variation in the soluble solid content, the acidity and the colour of the tomatoes, whether grown under sprinkler or drip irrigation. Unlike that observed in the present study, Prieto, Lopes and Ballesteros (1999) found that fruits produced under sprinkler irrigation were firmer than those produced under a drip system. This difference may be related to the fact that the tomato cultivars and climatic conditions in both studies were different. Additionally, the greater occurrence of late blight may have helped produce less firm fruits in those treatments under sprinkler irrigation. According to Reis (2010), fruit infected by P. infestans can soften over time due to subsequent contamination by opportunistic microorganisms.

\section{CONCLUSIONS}

1. The yield and weight of the tomato fruit were not affected by the irrigation or cultivation systems evaluated, under the dry season conditions found in Central Brazil, the coriander showing greater productivity when irrigated by sprinkling;

2. The water productivity index of those tomato plants under drip irrigation was higher than that from sprinkler irrigation;

3. The use of sprinkler irrigation reduced attack to the fruits by T. absoluta, as well as giving excellent control of L. taurica in the tomato plants;

4. The severity of $P$. infestans on the tomato plants can be maintained at low levels when employing drip irrigation, even in the presence of dew and during the early hours of the morning;

5. The smaller volume of soil used by the roots, the higher percentage of damage to the fruit by $T$. Absolute, and the high severity of L. taurica in the tomato under drip irrigation limited the production potential of the plants;

6. Intercropping tomato with coriander plants reduces the damage caused by borer insects to the tomato fruits, being a promising strategy for the ecological management of $T$. absoluta and $S$. eridania in organic production systems. 


\section{ACKNOWLEDGEMENTS}

The authors wish to thank the Centro de Desenvolvimento Tecnológico da Agricultura Orgânica do Distrito Federal (CDTOrg-DF) and the Conselho Nacional de Desenvolvimento Científico e Tecnológico (CNPq) for their partial financial support of this study.

\section{REFERENCES}

BOFF, P.; ZAMBOLIM, L.; VALE, F. X. R. Escalas para avaliação de severidade da mancha de estenfílio (Stemphylium solani) e da pinta preta (Alternaria solani) em tomateiro. Fitopatologia Brasileira, v. 16, p. 280-283, 1991.

BRANCO, R. B. F. et al. Cultivo orgânico sequencial de hortaliças com dois sistemas de irrigação e duas coberturas de solo. Horticultura Brasileira, v. 28, n. 1, p. 75-80, 2010.

CARVAlHO, A. M. et al. Produtividade, florescimento prematuro e queima-das-folhas em cenoura cultivada em sistema orgânico e convencional. Horticultura Brasileira, v. 23 , n. 2 , p. $250-254,2005$

FERERES, E.; GOLDHAMER, D .A.; PARSONS, L. R. 2003. Irrigation water management of horticultural crops. Hortscience, v. 38, n. 5, p. 1036-1042, 2003.

FERREIRA, S. M. R., FREITAS, R. J. S.; LAZZARI, E. N. Padrão de identidade e qualidade do tomate (Lycopersicon esculentum Mill.) de mesa. Ciência Rural, v. 34, n. 1, p. 329-335, 2004

HANSON, B.; MAY, D. Effect of subsurface dripirrigation on processing tomato yield, water table depth, soil salinity, and profitability. Agricultura Water Management, v. 68, n. 1, p. 1-17, 2004.

JAMES, W. C. Assessment keys. Canadian Plant Disease Survey, v. 51, p. 39-65, 1971.

LOPES, C. A.; MAROUElLI, W. A.; CAFÉ FILHO, A. C. Associação da irrigação com doenças de hortaliças. Revisão Anual de Patologia de Plantas, v. 14, p. 151-179, 2006.

MAROUELLI, W. A.; LOPES, C. A.; SILVA, W. L. C. Incidência de murcha-bacteriana em tomate para processamento industrial sob irrigação por gotejamento e aspersão. Horticultura Brasileira, v. 23, n. 2, p. 320-323, 2005.

MAROUELLI, W. A. et al. Produção de tomateiro orgânico irrigado por aspersão e gotejamento, em cultivo solteiro e consorciado com coentro. Horticultura Brasileira, v. 29, n. 3, p. 429-434, 2011a.

MAROUELLI, W. A. et al. Manejo da água de irrigação. In: SOUSA, V. F. et al. (Ed.). Irrigação e fertirrigação em fruteiras e hortaliças. Brasília: Embrapa Informação Tecnológica, 2011b. p. 157-232.

MAROUELLI, W. A. et al. Avaliação técnica e econômica do espaçamento de gotejadores em tomateiro para processamento cultivado em fileiras simples e duplas. Horticultura Brasileira, v. 21, n. 2, p. 202-206, 2003.

MAROUELLI, W. A.; SILVA, W. L. C. Water tension thresholds for processing tomatoes under drip irrigation in Central Brazil. Irrigation Science, v. 25, p. 411-418, 2007.

MEDEIROS, M. A.; SUJII, E. R.; MORAIS, H. C. Effect of plant diversification on abundance of South American Tomato Pinworm and predators in two cropping systems. Horticultura Brasileira, v. 27, n. 3, p. 300-306, 2009.

MEDEIROS, M. A.; SUJII, E. R.; MORAIS, H. C. Fatores de mortalidade na fase de ovo de Tuta absoluta em sistemas de produção orgânica e convencional de tomate. Bragantia, v. 70, p. 72-80, 2011

MORETTI, C. L. Protocolos de avaliação da qualidade química e física de tomate. Brasília: Embrapa Hortaliças, 2006. 12 p. (Comunicado Técnico, 32).

NOGUEIRA, A. R. A.; SOUZA, G. B. Manual de laboratório: solo, água, nutrição vegetal, nutrição animal e alimentos. São Carlos: Embrapa Pecuária Sudeste, 2005. 334 p.

PHENE, C. J.; HUTMACKER, R. B.; DAVIS, K. R. Two hundred tons per hectare of processing tomatoes - can we reach it? Hort Technology, v. 2, n. 1, p. 16-22, 1992.

PRIETO, M. H; LÓPES, J; BALLESTEROS, R. Influence of irrigation system and strategy on the agronomic and quality parameters of the processing tomato in Extremadura. Acta Horticulturae, n. 487, p. 575-579, 1999.

REIS, A. Requeima: doença destrutiva e comum ao tomateiro e à batateira. Brasília: Embrapa Hortaliças, 2010. 7 p. (Comunicado Técnico, 78).

SCHALLENBERGER, E. et al. Comportamento de plantas de tomateiros no sistema orgânico de produção em abrigos de cultivo com telas antiinsetos. Revista de Ciências Agroveterinárias, v. 7, n. 1, p. 23-29, 2008.

SMITH, R. et al. Cilantro production in California. Richmond: University of California: ANR Communication Services, 2011. 4 p. (Publication, 7236).

TOGNI, P.H. B. et al. Odour masking of tomato by coriander volatiles in host plant selection of Bemisia tabaci biotype B. Entomologia Experimentalis et Applicata, v. 136, n. 2, p. 164-173, 2010.

TOGNI, P. H. B. et al. Dinâmica populacional da moscabranca em tomateiro sob monocultivo e consórcio, cultivo orgânico e convencional. Horticultura Brasileira, v. 27, n. 2, p. 179-184, 2009. 